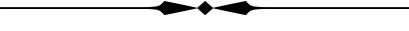

Competing Visions of Empire 
This page intentionally left blank 


\section{Competing VISIONS OF EMPIRE

\author{
Labor, Slavery, \\ and the Origins of \\ the British Atlantic Empire
} \\ Abigail L. Swingen}

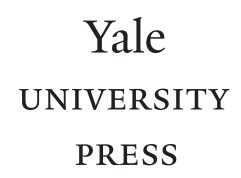

New Haven E London 
Published with assistance from the Annie Burr Lewis Fund.

Copyright (C) 2015 by Yale University. All rights reserved.

This book may not be reproduced, in whole or in part, including illustrations, in any form (beyond that copying permitted by Sections 107 and 108 of the U.S. Copyright Law and except by reviewers for the public press), without written permission from the publishers.

Yale University Press books may be purchased in quantity for educational, business, or promotional use. For information, please e-mail sales.press@yale.edu (U.S. office) or sales@yaleup.co.uk (U.K. office).

Set in PostScript Electra and Trajan types by IDS Infotech Ltd.

Printed in the United States of America.

Library of Congress Cataloging-in-Publication Data

Swingen, Abigail Leslie.

Competing visions of empire : labor, slavery, and the origins of the British Atlantic empire / Abigail L. Swingen.

pages $\mathrm{cm}$

Includes bibliographical references and index.

ISBN 978-0-300-18754-o (cloth : alk. paper) 1. West Indies, British-History - 17th century. 2. West Indies, British-Economic conditions - 17th century. 3. West Indies,

British-Commerce. 4. Slavery-West Indies, British-History - 17th century.

5. West Indies, British-Historiography. 6. Imperialism-History. 7. West Indies, British-History - 18th century. 8. West Indies, British-Economic conditions - 18th century. 9. Slavery -West Indies, British-History -18th century. I. Title.

$$
\begin{gathered}
\mathrm{F}_{2131 . S 942015} \\
972.9{ }^{\prime} 03-\mathrm{dc} 23 \\
2014027080
\end{gathered}
$$

A catalogue record for this book is available from the British Library.

This paper meets the requirements of ANSI/NISO Z39.48-1992 (Permanence of Paper).

$$
10987654321
$$




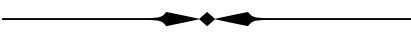

To Alan and Ruby 
This page intentionally left blank 